\title{
EVALUASI KESESUAIAN LAHAN UNTUK TANAMAN LAHAN SAWAH DI KECAMATAN HAMPARAN PERAK KABUPATEN DELI
}

\author{
Silvia Nora ${ }^{1 *}$, Abdul Rauf ${ }^{2} \&$ Deni Elfiati ${ }^{2}$ \\ 1 Sekolah Tinggi Ilmu Pertanian (STTP) \\ 2 Program Studi Pasca Sarjana Fakultas Pertanian USU, Medan 20155 \\ *Corresponding author: silvianora98@gmail.com
}

\begin{abstract}
ABSTRAK
Kecamatan Hamparan Perak Kabupaten Deli Serdang memiliki luas lahan pertanian \pm 11.046 ha atau 48, $9 \%$ dari luas Kecamatan ini, dimana seluas 7.048 ha adalah lahan sawah yang potensial namun belum dimanfaatkan secara optimal. Berdasarkan UU No 41 tahun 2009 bahwa perencanaan pengembangan lahan pertanian pangan berkelanjutan harus berdasarkan pada kriteria kesesuaian lahan yang dapa dilakukan dengan dukungan penelitian. Penelitian ini bertujuan untuk mengevaluasi karakteristik tingkat kesesuaian lahan sawah dan lahan kering di Kecamatan Hamparan Perak Kabupaten Deli Serdang, untuk menganalisis usaha-usaha perbaikan yang perlu dilakukan dalam meningkatkan produktivitas tanaman dan untuk membuat peta kesesuaian lahan aktual dan kesesuaian lahan potensial tanaman padi sawah dan beberapa tanaman lahan kering di Kecamatan Hamparan Perak Kabupaten Deli Serdang. Metode analisisnya adalah dengan metode membandingkan (matching) menurut FAO. pemilihan satuan unit lahan berdasarkan peta tanah yang terdiri dari 12 titik bor dan 6 lobang profil. Hasil penelitian menunjukkan bahwa tingkat kesesuaian lahan untuk tanaman padi sawah (Oryza sativa) adalah cukup sesuai $\left(S_{2}\right)$ seluas $14.093,883$ ha dan sesuai marginal $\left(S_{3}\right)$ seluas 17.347,141 ha. Untuk tanaman jagung (Zea mays) termasuk cukup sesuai $\left(\mathrm{S}_{2}\right)$ seluas $19.391,019$ ha dan sesuai marginal $\left(\mathrm{S}_{3}\right)$ seluas $12.050,005$ ha. Untuk tanaman kedelai (Glicine max) termasuk sesuai marginal $\left(\mathrm{S}_{3}\right)$ seluas 31.441,024 ha. Untuk tanaman ubi kayu (Manihot utilissima) termasuk kelas sesuai marginal $\left(\mathrm{S}_{3}\right)$ seluas 31.441,024 ha. Untuk tanaman ubi jalar (Ipomea batatas) termasuk kelas sesuai marginal $\left(\mathrm{S}_{3}\right)$ seluas 31.441,024 ha. Untuk tanaman sawo (Achras zapota) termasuk kelas cukup sesuai $\left(\mathrm{S}_{2}\right)$ seluas 17.660,583 ha dan kelas sesuai marginal $\left(\mathrm{S}_{3}\right)$ seluas $13.780,441$ ha. Untuk tanaman mangga (Mangifera indica) termasuk kelas sesuai marginal $\left(\mathrm{S}_{3}\right)$ seluas $31.441,024$ ha. Untuk tanaman sukun (Astocarpus astilis) termasuk kelas cukup sesuai $\left(\mathrm{S}_{2}\right)$ seluas $17.660,58$ ha dan kelas sesuai marginal $\left(\mathrm{S}_{3}\right)$ seluas $13.780,44$ ha.
\end{abstract}

Kata Kunci : Evaluasi kesesuaian lahan, tanaman lahan sawah, tanaman lahan kering, Kecamatan Hamparan Perak.

\section{PENDAHULUAN}

Kecamatan Hamparan Perak Kabupaten Deli Serdang berdasarkan analisa Geographical Information System (GIS) memiliki luas 31.441,024 ha. Namun menurut BPS (2015) luas wilayah Kecamatan Hamparan Perak adalah $230,15 \mathrm{~km}^{2}$ atau 23.015 ha dan
Suhedi (2015) mengatakan luas wilayah ini lebih kurang 22.611,57 hektar. Dari luasan tersebut, seluas 7.048 ha adalah lahan sawah dan 3.998 ha adalah lahan kering yang belum dimanfaatkan secara optimal. Luas lahan pertanian potensial di Kecamatan Hamparan Perak \pm 11.046 ha atau 48, $9 \%$ dari luas Kecamatan ini. 
Menurut UU No. 41 tahun 2009 tentang perlindungan lahan pertanian pangan berkelanjutan, bahwa lahanlahan potensial untuk pertanian tanaman pangan tidak boleh di alih fungsikan dan perlu dilindungi pemanfaatannya agar kesesuaian dan ketersediaannya tetap terkendali untuk dimanfaatkan pada masa yang akan datang selain itu perencanaan pengembangan lahan pertanian pangan berkelanjutan harus berdasarkan pada kriteria kesesuaian lahan.

Evaluasi lahan untuk keperluan perencanaan memiliki peran penting karena hampir tidak ada aktifitas yang dilakukan tanpa daya dukung lahan. Pemerintah menyarankan agar kegiatan evaluasi lahan di adakan secara luas sebagai kebijakan perencanaan kawasan indonesia, baik sebagai bagian dari pengaturan yang dituangkan melalui perbaikan UU No. 24 tahun 1992 tentang Penataan Ruang maupun melalui kegiatan nyata untuk memetakan potensi dan rancangan penggunaan lahan sesuai kebutuhan pembangunan dan pertumbuhan ekonomi Indonesia.

Dengan dilakukannya evaluasi kesesuaian lahan diharapkan akan diperoleh data-data karakteristik lahan yang akan menunjukkan sifat-sifat lahan sehingga dapat diketahui tingkat kesesuaian lahannya terutama terhadap tanaman lahan sawah dan lahan kering. Kemudian dilakukan usaha-usaha yang sesuai dengan karakteristik lahan yang pada akhirnya akan mengoptimalkan produksi tanaman.

Untuk itu perlu dilakukan penelitian kesesuaian lahan dalam rangka perencanaan lahan pertanian berkelanjutan agar produktivitas lahan dapat di tingkatkan sehingga dapat diatasi faktor-faktor penghambatnya dengan tepat dan optimal terutama untuk tanaman padi sawah dan beberapa tanaman lahan kering (jagung, kedelai, ubi kayu, ubi jalar, sawo, mangga dan sukun).

\section{BAHAN DAN METODE}

Kecamatan Hamparan Perak Kabupaten Deli Serdang memiliki luas 31.441,024 ha (Analisis GIS, 2015) terdiri dari 20 desa yang berada pada garis lintang $3^{\circ} 38^{\prime} 0^{\prime \prime}$ sampai $3^{\circ} 54^{\prime} 0^{\prime \prime}$ dan garis bujur 98 30'00" sampai 98०42'00" (Gambar 1). Ketinggian tempat $13-28$ $\mathrm{m}$ dpl dengan kemiringan lereng 0-15\% tetapi di dominasi oleh lereng <2\% (datar). Kecamatan Hamparan Perak memiliki curah hujan 1600-2400 $\mathrm{mm} /$ tahun, Temperatur rata-rata tahunan $27,1^{\circ} \mathrm{C}$ dan Kelembaban 84,14 \% (Data dari Stasiun Klimatologi Sampali Medan dari tahun 2004- 2014). Adapun batasbatas wilayah Kecamatan ini menurut Suhedy (2014) adalah sebagai berikut: (1) Sebelah Utara berbatas dengan Kecamatan Percut Sei Tuan, (2) Sebelah Selatan berbatas dengan Kecamatan Sunggal, (3) Sebelah Barat berbatas dengan Kecamatan Medan Sunggal dan (4) Sebelah Timur berbatas dengan Kecamatan Stabat Kabupaten Langkat Penelitian ini dilakukan dengan menggunakan metoda survei yang terdiri dari lima tahap yaitu persiapan, pra survei, survei utama, analisis tanah di Laboratorium serta pengolahan data.

\section{Tahap Persiapan}

Pada tahap persiapan dilakukan studi literatur dan pengumpulan data sekunder lokasi penelitian yaitu data iklim selama 10 tahun terakhir di BMKG kelas I Sampali Medan meliputi curah hujan, bulan kering, suhu udara, kelembaban dan sifat fisik lingkungan Kecamatan Hamparan Perak serta petapeta yang diperlukan (peta administrasi, peta tutupan lahan, peta jenis tanah, peta topografi). Pada tahap ini juga dilakukan penelaahan peta tutupan lahan dan peta jenis tanah menggunakan program 
Geographical Information System (GIS) sehingga diperoleh peta satuan unit lahan.

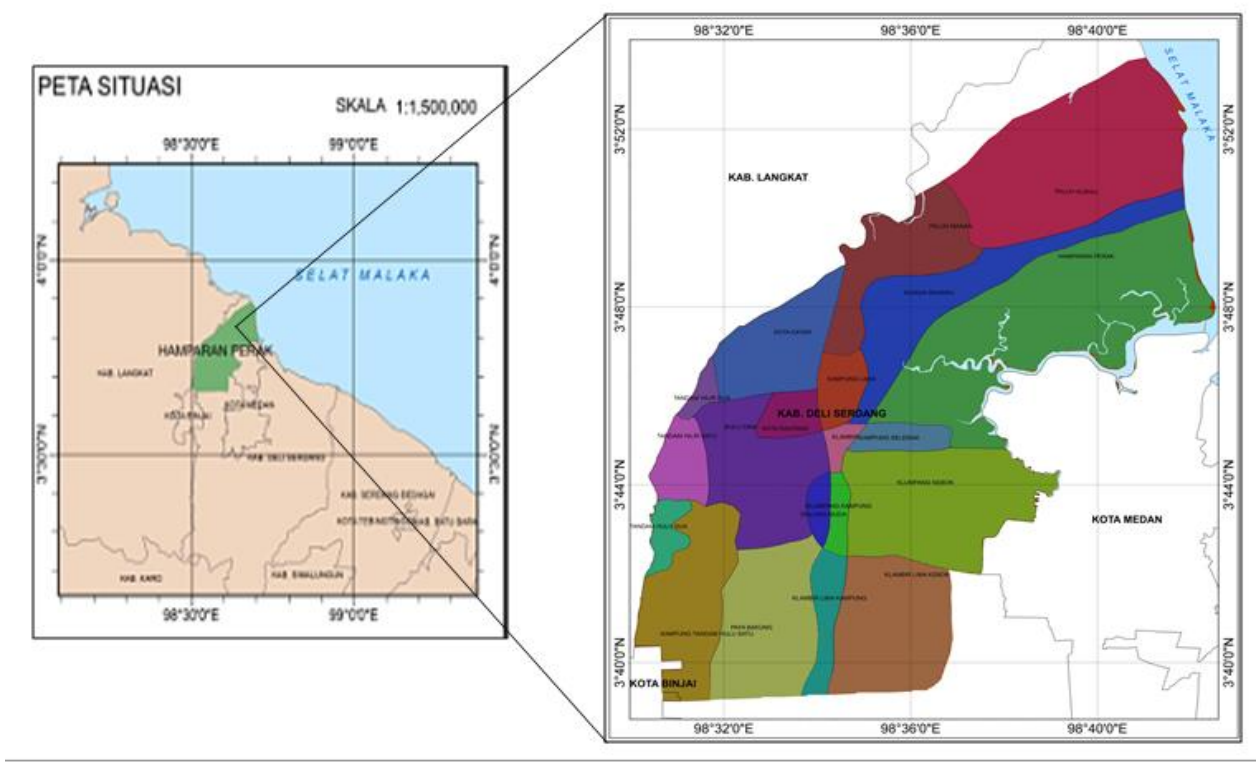

Gambar 1. Peta Lokasi Penelitian

\section{Pra survei}

Pada tahap ini dilakukan pengamatan faktor penyusun satuan lahan yang dipilih, serta mencek kebenaran informasi pada satuan lahan dan tanah yang berguna untuk menganalisis kesesuaian lahannya. Secara umum diamati antara lain bentuk wilayah, kelerengan dan penggunaan lahan

\section{Survei utama}

Pada tahap ini dilakukan pengamatan lapangan dan pengambilan sampel tanah secara purposive sampling

\section{Pengamatan lapangan}

Pengamatan di lapangan dilakukan meliputi pengamatan fisik lingkungan yaitu karakteristik lahan yang berpengaruh terhadap penggunaannya antara lain: derajat lereng, vegetasi, ketinggian tempat, erosi, banjir, bentuk lahan, batuan dipermukaan dan singkapan batuan serta parameter yang ada pada kriteria kelas kesesuaian lahan untuk tanaman yang dipilih.

\section{Pengambilan sampel tanah}

Pengambilan sampel tanah dilakukan pada areal satuan lahan berdasarkan peta tanah dengan cara pemboran. Titik yang di pilih mewakili masing-masing great group tanah dimana untuk great group Andaquepts, Tropaquepts terdapat pada Desa Paya Bakung dan Desa Tandam Hilir Satu. Great group Tropaquept, Fluvaquents terdapat pada Desa Paluh Kurau, Kota Rantang, Kota Datar, Paluh Manan dan Kampung Lama. Untuk great group Hydraquent, Sulfaquents terdapat pada desa Hamparan Perak. Terdapat sebanyak 20 titik sampel yang kemudian dikompositkan menjadi 12 sampel pengamatan (Gambar 2). Penentuan nilai karakteristik lahan untuk sampel tanah dilakukan dengan menggunakan bor tanah pada kedalaman 0-30 cm dan 0-60 
cm. Penentuan sifat kimia tanah dilakukan dengan analisa tanah di Laboratorium.

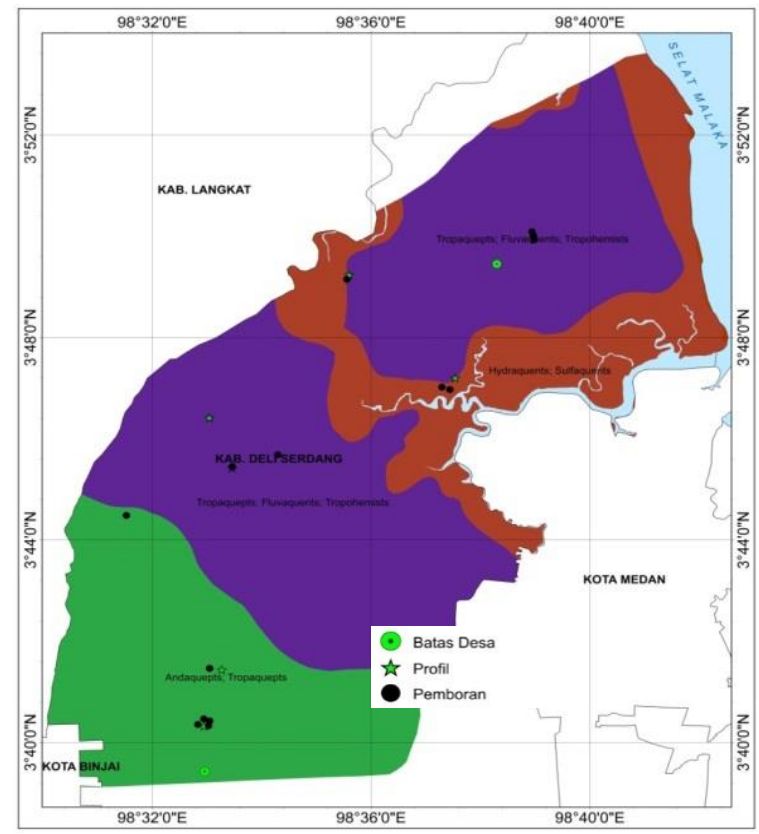

Gambar 2. Titik Pemboran dan Lobang Profil

\section{Analisis tanah di Laboratorium}

Analisis contoh tanah di Laboratorium meliputi : (1) Penetapan tekstur tanah (2) Analisis C-Organik tanah 3) Analisis kation- kation basa : $\mathrm{Ca}^{2+}, \mathrm{Mg}^{2+}, \mathrm{K}^{+}, \mathrm{Na}^{+}$(4) Penetapan KTK (5) Penetapan $\mathrm{pH}$ Tanah (6) Penetapan P- tersedia (7) Penetapan N-total dan (8) Penetapan Salinitas dengan metoda elektrometrik

\section{Pengolahan Data}

Data yang diperoleh dari analisis di Laboratorium dan lapangan tentang karakteristik lahan pada daerah penelitian disusun dalam bentuk tabel sebagai data kualitas atau karakteristik lahan dan kemudian dibandingkan dengan kebutuhan tanaman pada tingkat semi detil. Evaluasi kesesuaian lahan menggunakan system matching (mencocokan), serta membandingkan antara karakteristik lahan dengan persyaratan tumbuh tanaman yang di formulasikan dalam petunjuk teknis evaluasi lahan untuk Komoditas Pertanian (Hardjowigeno, 2007 ; Ritung et al, 2011). Pada proses matching di gunakan hukum minimum Leibig untuk menentukan faktor pembatas yang akan mempengaruhi kelas dan sub kelas kesesuaian lahannya. Persyaratan tumbuh tanaman menjadi kriteria dalam evaluasi kesesuaian lahan. Hasil kesesuaian lahan masing- masing komoditas tanaman lahan sawah dan lahan kering ditampilkan dalam bentuk tabel kesesuaian lahan aktual dan potensial menggunakan perangkat lunak GIS. Selanjutnya dipetakan kesesuaian lahan aktual dan kesesuian lahan potensialnya. 
HASIL DAN PEMBAHASAN

\section{Karakteristik lahan}

Karakteristik lahan Kecamatan

Hamparan Perak Kabupaten Deli

Serdang untuk lahan Sawah disajikan tabel 1 . Nilai pH tanah di Kecamatan Hamparan Perak bervariasi dari 5,3 (masam) sampai 6,9 (netral). Nilai Ntotal dan $\mathrm{K}_{2} \mathrm{O}$ pada lahan sawah ratarata tergolong rendah. Hal ini di sebabkan karena terkurasnya unsur hara setelah ditanami padi. Nilai $\mathrm{P}_{2} \mathrm{O}_{5}$ tergolong sedang sampai tinggi.

Menurut Sharma et al (2008), P

Tersedia yang sedang/tinggi di sebabkan oleh pengaruh penambahan pupuk yang mengandung unsur $\mathrm{P}$ dan hara $\mathrm{P}$ yang banyak di fiksasi oleh tanah.Untuk meningkatkan nilai N-total tanah, selain menggunakan pupuk buatan bisa dimanfaatkan bahan organik karena sumber utama unsur $\mathrm{N}$ selain pupuk buatan adalah bahan organik.Kejenuhan basa di wilayah ini termasuk tinggi sampai sangat tinggi

Tabel 1. Nilai karakteristik lahan sawah di Kecamatan Hamparan Perak

\begin{tabular}{|c|c|c|c|c|c|c|}
\hline \multirow{2}{*}{$\begin{array}{c}\text { Karakteristik } \\
\text { Lahan }\end{array}$} & \multicolumn{2}{|c|}{ Payabakung } & \multicolumn{2}{|c|}{ Paluh manan } & \multicolumn{2}{|c|}{ Hamparan Perak } \\
\hline & $0-30 \mathrm{~cm}$ & $30-60 \mathrm{~cm}$ & $0-30 \mathrm{~cm}$ & $30-60 \mathrm{~cm}$ & $0-30 \mathrm{~cm}$ & $30-60 \mathrm{~cm}$ \\
\hline $\begin{array}{l}\text { Temperatur rata- } \\
\text { rata tahunan }\left({ }^{\circ} \mathrm{C}\right)\end{array}$ & 27,01 & 27,01 & 27,01 & 27,01 & 27,01 & 27,01 \\
\hline $\begin{array}{l}\text { Bulan Kering } \\
(\mathrm{mm})\end{array}$ & $2-3$ bulan & 2-3 bulan & $2-3$ bulan & $2-3$ bulan & 2-3 bulan & $2-3$ bulan \\
\hline Kelembaban (\%) & 84,14 & 84,14 & 84,14 & 84,14 & 84,14 & 84,14 \\
\hline $\begin{array}{l}\text { Curah hujan } \\
\text { tahunan (mm) }\end{array}$ & 2296 & 2296 & 2296 & 2296 & 2296 & 2296 \\
\hline $\begin{array}{l}\text { Ketinggian } \\
(\mathrm{m} \text { dpl) }\end{array}$ & 18 & 18 & 17 & 17 & 14 & 14 \\
\hline Drainase & $\begin{array}{c}\text { agak } \\
\text { terhambat }\end{array}$ & terhambat & terhambat & terhambat & $\begin{array}{c}\text { agak } \\
\text { terhambat }\end{array}$ & terhambat \\
\hline Tekstur & $\begin{array}{c}\text { Lempung } \\
\text { berliat }\end{array}$ & $\begin{array}{c}\text { Lempung } \\
\text { berliat }\end{array}$ & $\begin{array}{c}\text { Lempung } \\
\text { berliat }\end{array}$ & $\begin{array}{c}\text { Lempung } \\
\text { berliat }\end{array}$ & lempung & $\begin{array}{l}\text { Lempung } \\
\text { berpasir }\end{array}$ \\
\hline $\begin{array}{l}\text { Kedalaman efektif } \\
(\mathrm{cm})\end{array}$ & 100 & 100 & 100 & 100 & 76 & 76 \\
\hline KTK (me/100g) & $26,51(\mathrm{~T})$ & $29,6(\mathrm{~T})$ & $11,23(\mathrm{R})$ & $12,25(\mathrm{R})$ & $18,15(\mathrm{~S})$ & $15,41(\mathrm{R})$ \\
\hline $\mathrm{pH}$ Tanah & 5,3 & 6,9 & 5,3 & 6 & 5,5 & 6,7 \\
\hline N-total $(\%)$ & $0,22(\mathrm{~S})$ & 0,07 (SR) & $0,17(\mathrm{R})$ & 0,08 (SR) & $0,15(\mathrm{R})$ & $0,17(\mathrm{R})$ \\
\hline $\mathrm{P}_{2} \mathrm{O}_{5}(\mathrm{ppm})$ & $5,84(\mathrm{R})$ & $16,44(\mathrm{ST})$ & $15,21(\mathrm{ST})$ & $16,5(\mathrm{ST})$ & $27,28(\mathrm{ST})$ & $13,19(\mathrm{~T})$ \\
\hline $\mathrm{K}_{2} \mathrm{O}(\mathrm{me} / 100 \mathrm{~g})$ & $0,16(\mathrm{R})$ & $0,15(\mathrm{R})$ & $0,42(\mathrm{~S})$ & $0,14(\mathrm{R})$ & $0,61(\mathrm{~T})$ & $0,2(\mathrm{R})$ \\
\hline C-organik (\%) & $1,36(\mathrm{R})$ & 0,13 (SR) & 0,96 (SR) & 0,48 (SR) & $0,87(\mathrm{SR})$ & 0,17 (SR) \\
\hline $\mathrm{KB}(\%)$ & $98,76(\mathrm{ST})$ & $103,92(\mathrm{ST})$ & $96,26(\mathrm{ST})$ & $91,27(\mathrm{ST})$ & $106,01(\mathrm{ST})$ & $97,6(\mathrm{ST})$ \\
\hline Salinitas (ds/m) & $0,094(\mathrm{SR})$ & $0,044(\mathrm{SR})$ & $0,025(\mathrm{SR})$ & $0,065(\mathrm{SR})$ & 0,04 (SR) & $0,064(\mathrm{SR})$ \\
\hline Lereng (\%) & $<2$ & $<2$ & $<2$ & $<2$ & $<2$ & $<2$ \\
\hline $\begin{array}{l}\text { Batuan } \\
\text { dipermukaan }(\%)\end{array}$ & 0 & 0 & 0 & 0 & 0 & 0 \\
\hline $\begin{array}{l}\text { Singkapan batuan } \\
(\%)\end{array}$ & 0 & 0 & 0 & 0 & 0 & 0 \\
\hline $\begin{array}{l}\text { Tingkat Bahaya } \\
\text { erosi }\end{array}$ & SR & SR & SR & SR & SR & SR \\
\hline Bahaya Banjir & $\mathrm{F} 1$ & $\mathrm{~F} 1$ & $\mathrm{~F} 1$ & $\mathrm{~F} 1$ & $\mathrm{~F} 1$ & F1 \\
\hline $\begin{array}{r}\text { eterangan: } \mathrm{ST}=\mathrm{S} \\
\mathrm{T}=\mathrm{T} \\
\mathrm{S}=\mathrm{Se}\end{array}$ & $\begin{array}{l}\text { gat tinggi } \\
\text { gi } \\
\text { ng }\end{array}$ & $\begin{array}{l}\mathrm{R}=\text { rendah } \\
\mathrm{SR}=\text { sangat } \\
\mathrm{F} 1=\text { bahay: }\end{array}$ & $\begin{array}{l}\text { dah } \\
\text { njir ringar }\end{array}$ & & & \\
\hline
\end{tabular}


Kejenuhan Basa merupakan salah satu indikator kesuburan kimia tanah. Tanah yang subur adalah tanah dengan kejenuhan basa tinggi sebab belum terjadi pencucian tanah yang serius. Sebaliknya, tanah dengan kejenuhan basa rendah menandakan tanah tersebut asam sehingga menghambat penyerapan unsur hara oleh akar tanaman (Indranada, 1986). COrganik tergolong rendah sehingga perlu penambahan bahan organik. Bahan organik tanah mengandung semua hara termasuk humus yang sangat diperlukan untuk pertumbuhan tanaman. Peran bahan organik terhadap ketersediaan hara dalam tanah tidak terlepas dengan proses mineralisasi yang merupakan tahap akhir dari proses perombakan bahan organik. Bahan organik memiliki peranan kimia dalam menyediakan $\mathrm{N}, \mathrm{P}$, dan S untuk tanaman

\section{Evaluasi kesesuaian Lahan}

Penentuan kelas kesesuaian lahan untuk padi sawah berdasarkan nilai data pada kedalaman 0-30 $\mathrm{cm}$ dengan asumsi bahwa tanaman padi sawah memiliki perakaran yang dangkal.

\section{Kelas kesesuaian lahan untuk tanaman Padi sawah}

Penilaian kesesuaian lahan tingkat semi detil untuk tanaman Padi sawah di Desa Payabakung Kecamatan Hamparan Perak Kabupaten Deli Serdang di sajikan pada Tabel 3.

\section{Faktor-faktor} pembatas kesesuaian lahan untuk tanaman padi sawah di Desa Payabakung yang dapat diperbaiki adalah C-Organik, $\mathrm{P}_{2} \mathrm{O}_{5}$ dan $\mathrm{K}_{2} \mathrm{O}$ tanah. Dari Tabel 3, terlihat bahwa usaha perbaikan perlu dilakukan pada faktor pembatas C-organik yang diperbaiki dengan tingkat pengelolaan tinggi yaitu dengan penambahan bahan organik. Kebutuhan C-organik tanaman padi sawah untuk kriteria sangat sesuai adalah $3 \%$ sedangkan ketersediaan Corganik yang terdapat pada tanah sawah saat penelitian adalah 1,36 \% sehingga diperlukan penambahan $1,64 \%$ yang setara dengan 32,8 ton Carbon/ha atau 56,55 ton bahan organik/ha. Dengan demikian kesesuaian untuk C-organik menjadi sangat sesuai $\left(\mathrm{S}_{1}\right)$ dari kelas cukup sesuai $\left(\mathrm{S}_{2}\right)$.

Faktor pembatas $\mathrm{P}_{2} \mathrm{O}_{5}$ tanah dapat diperbaiki dengan tingkat pengelolaan rendah yaitu dengan pemupukan sesuai kebutuhan tanaman. Perkiraan kebutuhan $\mathrm{P}_{2} \mathrm{O}_{5}$ tanaman padi sawah untuk kriteria sangat sesuai diperlukan 11 ppm sedangkan ketersediaan $\mathrm{P}_{2} \mathrm{O}_{5}$ yang terdapat pada tanah sawah saat penelitian adalah 5,84 ppm sehingga idealnya diperlukan penambahan 5,16 ppm setara dengan 103,2 $\mathrm{Kg} \mathrm{P}_{2} \mathrm{O}_{5} / \mathrm{ha}$ atau $286,7 \mathrm{Kg} \mathrm{SP}_{36} / \mathrm{ha}$. Total pupuk yang di butuhkan untuk padi sawah di daerah itu diperlukan tambahan rata-rata $25 \%$ untuk memenuhi kebutuhan mikroba dan kehilangan fosfat sehingga perlu penambahan pupuk sekitar $129 \mathrm{Kg}$ $\mathrm{P}_{2} \mathrm{O}_{5} / \mathrm{ha}$ atau $358,375 \mathrm{~kg} \quad \mathrm{SP}_{36} / \mathrm{ha}$. Dengan begitu kesesuaian lahan untuk pospat dapat menjadi cukup sesuai $\left(\mathrm{S}_{2}\right)$ dari kelas sesuai marginal $\left(\mathrm{S}_{3}\right)$.

Pada faktor pembatas $\mathrm{K}_{2} \mathrm{O}$ tanah
dapat diperbaiki dengan tingkat pengelolaan sedang sampai tinggi yaitu dengan pemupukan sesuai kebutuhan tanaman. Perkiraan kebutuhan $\mathrm{K}_{2} \mathrm{O}$ tanaman padi sawah untuk kriteria sangat sesuai diperlukan sebanyak 0,6 me/100 gr sedangkan ketersediaan $\mathrm{K}_{2} \mathrm{O}$ yang terdapat pada saat penelitian adalah 0,16 me/100 gr sehingga idealnya diperlukan penambahan sebanyak 0,44 me/100 gr yang setara dengan $88 \mathrm{~kg} \mathrm{~K}_{2} \mathrm{O}$ /ha atau $146,7 \mathrm{~kg} \mathrm{KCl} / \mathrm{ha}$. Total pupuk yang dibutuhkan untuk padi sawah didaerah itu diperlukan tambahan ratarata $25 \%$ untuk memenuhi kebutuhan mikroba dan kehilangan kalium 
sehingga perlu penambahan pupuk sebanyak $110 \mathrm{~K}_{2} \mathrm{O} / \mathrm{ha}$ atau $183,375 \mathrm{~kg}$ $\mathrm{KCl} / \mathrm{ha}$. Dengan begitu kesesuaian untuk kalium dapat menjadi sangat sesuai $\left(\mathrm{S}_{1}\right)$ dari kelas cukup sesuai $\left(\mathrm{S}_{2}\right)$.

Tabel 2. Penilaian kesesuaian lahan tingkat semi detil untuk tanaman Padi sawah di Desa Payabakung

\begin{tabular}{|c|c|c|c|c|c|c|}
\hline Karakteristik lahan & Nilai data & $\begin{array}{c}\text { Kesesuaian } \\
\text { lahan } \\
\text { aktual }\end{array}$ & $\begin{array}{c}\text { Faktor } \\
\text { pembatas } \\
\text { terberat }\end{array}$ & \multicolumn{2}{|c|}{$\begin{array}{c}\text { Usaha } \\
\text { perbaikan }\end{array}$} & $\begin{array}{c}\text { Kesesuaian } \\
\text { lahan } \\
\text { potensial }\end{array}$ \\
\hline Rejim suhu (t) & & & & & & \\
\hline Temperatur rata tahunan & 27,01 & $\mathrm{~S}_{1}$ & & & & $\mathrm{~S}_{1}$ \\
\hline \multicolumn{7}{|l|}{ Ketersediaan air (w) } \\
\hline Curah Hujan thn (mm) & 2296 & $\mathrm{~S}_{1}$ & & & & $\mathrm{~S}_{1}$ \\
\hline Bulan Kering & $2-3$ & $\mathrm{~S}_{1}$ & & & & $\mathrm{~S}_{1}$ \\
\hline Kelembaban rata-rata $(\%)$ & 84,14 & $\mathrm{~S}_{1}$ & & & & $\mathrm{~S}_{1}$ \\
\hline \multicolumn{7}{|l|}{ Media perakaran (r) } \\
\hline Drainase tanah & agak terhambat & $\mathrm{S}_{1}$ & & & & $\mathrm{~S}_{1}$ \\
\hline Tekstur tanah & lempung berliat & $\mathrm{S}_{1}$ & & & & $\mathrm{~S}_{1}$ \\
\hline Kedalaman efektif $(\mathrm{cm})$ & 100 & $\mathrm{~S}_{1}$ & & & & $\mathrm{~S}_{1}$ \\
\hline \multicolumn{7}{|l|}{ Retensi hara (f) } \\
\hline KTK (me/100g) & $26,51(\mathrm{~T})$ & $\mathrm{S}_{1}$ & & & & $\mathrm{~S}_{1}$ \\
\hline Kejenuhan Basa (\%) & $98,76(\mathrm{ST})$ & $\mathrm{S}_{1}$ & & & & $\mathrm{~S}_{1}$ \\
\hline $\mathrm{pH}$ tanah & 5,3 & $\mathrm{~S}_{1}$ & & & & $\mathrm{~S}_{1}$ \\
\hline C-organik (\%) & $1,36(\mathrm{R})$ & $\mathrm{S}_{2}$ & $\mathrm{f}$ & $\mathrm{O}$ & $\mathrm{S}$ & $\mathrm{S}_{1}$ \\
\hline Salinitas (mmhos/cm) (x) & 0,094 (SR) & $\mathrm{S}_{1}$ & & & & $\mathrm{~S}_{1}$ \\
\hline \multicolumn{7}{|l|}{ Ketersediaan Hara (n) } \\
\hline N-total $(\%)$ & $0,22(\mathrm{~S})$ & $\mathrm{S}_{1}$ & & & & $\mathrm{~S}_{1}$ \\
\hline $\mathrm{P}_{2} \mathrm{O}_{5}(\mathrm{ppm})$ & $5,84(\mathrm{R})$ & $\mathrm{S}_{3}$ & $\mathrm{n}$ & $\mathrm{P}$ & $\mathrm{S}$ & $\mathrm{S}_{2}$ \\
\hline $\mathrm{K}_{2} \mathrm{O}(\mathrm{mg} / 100 \mathrm{~g})$ & $0,16(\mathrm{R})$ & $\mathrm{S}_{2}$ & $\mathrm{n}$ & $\mathrm{P}$ & $\mathrm{S}, \mathrm{T}$ & $\mathrm{S}_{1}$ \\
\hline \multicolumn{7}{|l|}{ Penyiapan lahan (p) } \\
\hline Batuan dipermukaan (\%) & 0 & $\mathrm{~S}_{1}$ & & & & $\mathrm{~S}_{1}$ \\
\hline Singkapan batuan & 0 & $\mathrm{~S}_{1}$ & & & & $\mathrm{~S}_{1}$ \\
\hline \multicolumn{7}{|l|}{ Tingkat bahaya erosi (e) } \\
\hline Bahaya erosi & SR & $\mathrm{S}_{1}$ & & & & $\mathrm{~S}_{1}$ \\
\hline Lereng $(\%)$ & $<2$ & $\mathrm{~S}_{1}$ & & & & $\mathrm{~S}_{1}$ \\
\hline \multicolumn{7}{|l|}{ Bahaya banjir (b) } \\
\hline Periode banjir & $\mathrm{F} 1$ & $\mathrm{~S}_{1}$ & & & & $\mathrm{~S}_{1}$ \\
\hline \multicolumn{2}{|c|}{ Hasil kesesuaian lahan } & $\mathbf{S}_{3}(\mathbf{n})$ & & & & $\mathbf{S}_{2}(\mathbf{n})$ \\
\hline $\begin{aligned} \text { eterangan }: \text { S1 } & =\text { Sangat sesuai } \\
\text { S2 } & =\text { Cukup sesuai } \\
\text { S3 } & =\text { Sesuai Margin } \\
\text { S } & =\text { Sedang } \\
\text { R } & =\text { Rendah }\end{aligned}$ & & $\begin{array}{l}\mathrm{O}=\mathrm{Bhn} \\
\mathrm{P}=\text { Pem } \\
\mathrm{TP}=\text { Tingh } \\
\mathrm{T}=\text { Ting } \\
\text { Inp }=\text { inpt }\end{array}$ & $\begin{array}{l}\text { rganik } \\
\text { pukan } \\
\text { t Pengelolaan } \\
\text { i }\end{array}$ & & & \\
\hline
\end{tabular}

Hasil evaluasi kesesuaian lahan tingkat semi detil untuk tanaman padi sawah pada kesesuaian lahan aktual yaitu termasuk sesuai marginal dengan faktor pembatas $\mathrm{P}_{2} \mathrm{O}_{5}$ tanah (sub kelas $\mathrm{S}_{3}$ ). Kesesuaian lahan potensialnya termasuk kelas cukup sesuai $\left(\mathrm{S}_{2}\right)$. Pada Tabel 4, faktor-faktor pembatas kesesuaian lahan untuk tanaman padi sawah di Desa Paluh Manan yang perlu diperbaiki adalah KTK tanah, pH tanah,
C-organik dan N-total tanah. Dari Tabel 4, terlihat bahwa usaha perbaikan perlu dilakukan pada faktor pembatas KTK dan $\mathrm{pH}$ tanah dengan tingkat pengelolaan sedang yaitu KTK tanah dengan penambahan bahan organik dan $\mathrm{pH}$ tanah diperbaiki dengan proses penggenangan sehingga dari kelas cukup sesuai $\left(\mathrm{S}_{2}\right)$ pada kesesuaian lahan aktual menjadi sangat sesuai $\left(S_{1}\right)$ ditinjau dari kesesuaian lahan potensial. 
Tabel 3. Penilaian kesesuaian lahan tingkat semi detil untuk tanaman Padi sawah di Desa Paluh Manan

\begin{tabular}{|c|c|c|c|c|c|c|}
\hline \multirow[t]{2}{*}{ Karakteristik lahan } & \multirow[t]{2}{*}{ Nilai data } & \multirow{2}{*}{$\begin{array}{c}\text { Kesesuaian } \\
\text { lahan } \\
\text { aktual } \\
\end{array}$} & \multirow{2}{*}{$\begin{array}{c}\text { Faktor } \\
\text { pembatas } \\
\text { terberat }\end{array}$} & \multicolumn{2}{|c|}{$\begin{array}{c}\text { Usaha } \\
\text { perbaikan }\end{array}$} & \multirow{2}{*}{$\begin{array}{c}\text { Kesesuaian } \\
\text { lahan } \\
\text { potensial } \\
\end{array}$} \\
\hline & & & & & & \\
\hline \multicolumn{7}{|l|}{ Rejim suhu (t) } \\
\hline $\begin{array}{l}\text { Temperatur rata } \\
\text { tahunan }\left({ }^{\circ} \mathrm{C}\right)\end{array}$ & 27,01 & $\mathrm{~S}_{1}$ & & & & $\mathrm{~S}_{1}$ \\
\hline \multicolumn{7}{|l|}{ Ketersediaan air (w) } \\
\hline Curah Hujan thn (mm) & 2296 & $\mathrm{~S}_{1}$ & & & & $\mathrm{~S}_{1}$ \\
\hline Bulan Kering & $2-3$ & $\mathrm{~S}_{1}$ & & & & $\mathrm{~S}_{1}$ \\
\hline Kelembaban rata-rata $(\%)$ & 84,14 & $\mathrm{~S}_{1}$ & & & & $\mathrm{~S}_{1}$ \\
\hline \multicolumn{7}{|l|}{ Media perakaran (r) } \\
\hline Drainase tanah & Terhambat & $\mathrm{S}_{1}$ & & & & $\mathrm{~S}_{1}$ \\
\hline Tekstur tanah & Lempung berliat & $\mathrm{S}_{1}$ & & & & $\mathrm{~S}_{1}$ \\
\hline Kedalaman efektif $(\mathrm{cm})$ & 100 & $S_{1}$ & & & & $S_{1}$ \\
\hline \multicolumn{7}{|l|}{ Retensi hara (f) } \\
\hline KTK (me/100g) & $11,23(\mathrm{R})$ & $\mathrm{S}_{2}$ & $\mathrm{f}$ & $\mathrm{O}$ & $\mathrm{S}, \mathrm{T}$ & $\mathrm{S}_{1}$ \\
\hline Kejenuhan Basa (\%) & $96,26(\mathrm{ST})$ & $\mathrm{S}_{1}$ & & & & $\mathrm{~S}_{1}$ \\
\hline $\mathrm{pH}$ tanah & 5,3 & $\mathrm{~S}_{2}$ & $\mathrm{f}$ & $\mathrm{G}$ & $\mathrm{S}$ & $\mathrm{S}_{1}$ \\
\hline C-organik (\%) & 0,96 (SR) & $\mathrm{S}_{2}$ & $\mathrm{f}$ & $\mathrm{O}$ & $\mathrm{S}$ & $\mathrm{S}_{1}$ \\
\hline Salinitas $(\mathrm{mmhos} / \mathrm{cm})(\mathrm{x})$ & $0,025(\mathrm{SR})$ & $\mathrm{S}_{1}$ & & & & $\mathrm{~S}_{1}$ \\
\hline \multicolumn{7}{|l|}{ Ketersediaan Hara (n) } \\
\hline N-total (\%) & $0,17(\mathrm{R})$ & $\mathrm{S}_{2}$ & $\mathrm{n}$ & $\mathrm{P}$ & $\mathrm{S}$ & $\mathrm{S}_{1}$ \\
\hline $\mathrm{P}_{2} \mathrm{O}_{5}(\mathrm{ppm})$ & $15,21(\mathrm{ST})$ & $\mathrm{S}_{1}$ & & & & $\mathrm{~S}_{1}$ \\
\hline $\mathrm{K}_{2} \mathrm{O}(\mathrm{mg} / 100 \mathrm{~g})$ & $0,42(\mathrm{R})$ & $\mathrm{S}_{1}$ & & & & $\mathrm{~S}_{1}$ \\
\hline \multicolumn{7}{|l|}{ Penyiapan lahan (p) } \\
\hline Batuan dipermukaan (\%) & $0-2$ & $\mathrm{~S}_{1}$ & & & & $\mathrm{~S}_{1}$ \\
\hline Singkapan batuan & 0 & $\mathrm{~S}_{1}$ & & & & $\mathrm{~S}_{1}$ \\
\hline \multicolumn{7}{|l|}{ Tingkat bahaya erosi (e) } \\
\hline Bahaya erosi & SR & $\mathrm{S}_{1}$ & & & & $\mathrm{~S}_{1}$ \\
\hline Lereng (\%) & 0 & $\mathrm{~S}_{1}$ & & & & $\mathrm{~S}_{1}$ \\
\hline \multicolumn{7}{|l|}{ Bahaya banjir (b) } \\
\hline Periode banjir & $\mathrm{F} 1$ & $\mathrm{~S}_{1}$ & & & & $\mathrm{~S}_{1}$ \\
\hline \multicolumn{2}{|c|}{ Hasil kesesuaian lahan } & $S_{2}$ (fn) & & & & $\mathbf{S}_{1}$ \\
\hline $\begin{aligned} \text { eterangan }: \text { S1 } & =\text { Sangat sesuai } \\
\text { S2 } & =\text { Cukup sesuai } \\
\text { S3 } & =\text { Sesuai Marginal } \\
\text { S } & =\text { Sedang } \\
\mathrm{R} & =\text { Rendah } \\
\mathrm{T} & =\text { Tinggi }\end{aligned}$ & & $\begin{array}{l}\mathrm{O}=\mathrm{Bhn} \\
\mathrm{P}=\text { Pem } \\
\mathrm{TP}=\text { Ting } \\
\mathrm{G}=\mathrm{Gen} \\
\text { Inp }=\text { inp }\end{array}$ & $\begin{array}{l}\text { organik } \\
\text { pukan } \\
\text { at Pengelolaan } \\
\text { ngan }\end{array}$ & & & \\
\hline
\end{tabular}

Faktor pembatas C-organik yang diperbaiki dengan tingkat pengelolaan sedang yaitu dengan penambahan bahan organik. Perkiraan kebutuhan C-organik tanaman padi sawah untuk kriteria sangat sesuai diperlukan $3 \%$ sedangkan ketersedian C-organik yang terdapat pada tanah sawah pada saat penelitian adalah $0,96 \%$ sehingga idealnya diperlukan penambahan 2,04\% yang setara dengan 40,8 ton $\mathrm{C} /$ ha atau 70,34 ton bahan organik/ha. Namun demikian pemberian bahan organik ini dapat disesuaikan dengan kemampuan petani dan ketersediaan bahan organik yang ada di daerah tersebut. Dengan begitu kriteria kelas kesesuaian lahan untuk Corganik menjadi sangat sesuai $\left(S_{1}\right)$ dari kelas cukup sesuai $\left(\mathrm{S}_{2}\right)$.

Faktor pembatas N-total tanah dapat diperbaiki dengan tingkat pengelolaan sedang dengan pemupukan 
sesuai kebutuhan tanaman. Kebutuhan N-total tanaman padi sawah untuk kriteria sangat sesuai diperlukan 0,51\% sedangkan ketersediaan $\mathrm{N}$-total yang terdapat pada tanah sawah saat penelitian adalah $0,17 \%$ sehingga diperlukan penambahan $0,34 \%$ yang setara dengan $68 \mathrm{~kg} \mathrm{~N} / \mathrm{ha}$ atau 147,83 kg Urea/ha. Total pupuk yang diperlukan untuk tanaman padi sawah di daerah itu diperlukan penambahan $25 \%$ untuk memenuhi kebutuhan mikroba dan kehilangan $\mathrm{N}$ akibat leaching dan denitrifikasi sehingga diperlukan penambahan 72,25 $\mathrm{kg}$ N/ha atau $184,788 \mathrm{~kg}$ Urea/ha. Dengan demikian kriteria kelas kesesuaian $\mathrm{N}$-total menjadi sangat sesuai $\left(S_{1}\right)$ dari kelas cukup sesuai $\left(S_{2}\right)$.

Hasil evaluasi kesesuaian lahan tingkat semi detil untuk tanaman padi sawah pada kesesuaian lahan aktual yaitu termasuk cukup sesuai dengan faktor pembatas KTK dan N-total tanah (sub kelas $\mathrm{S}_{2}$ ). Kesesuaian lahan potensialnya termasuk kelas sangat sesuai $\left(\mathrm{S}_{1}\right)$.

Pada Tabel 5, faktor-faktor pembatas kesesuaian lahan untuk tanaman padi sawah di Desa Hamparan Perak yang perlu diperbaiki adalah $\mathrm{pH}$, C-organik dan N-total tanah.Faktor pembatas $\mathrm{pH}$ tanah dapat dilakukan usaha perbaikan dengan tingkat pengelolaan sedang yaitu meningkatkan $\mathrm{pH}$ tanah yang masam $(5,5)$ dengan penggenangan dan C-organik dengan penambahan bahan organik.

Perkiraan kebutuhan C-organik tanaman padi sawah untuk kriteria sangat sesuai diperlukan $3 \%$ sedangkan ketersediaan C-organik pada tanah sawah saat penelitian $0,87 \%$ sehingga idealnya diperlukan penambahan $2,13 \%$ yang setara dengan 42,6 ton $\mathrm{C} /$ ha atau 73 ton bahan organik/ha. Namun demikian pemberian bahan organik ini dapat disesuaikan dengan kemampuan petani dan ketersediaan bahan organik yang ada di daerah tersebut. Sehingga kriteria kelas kesesuaian lahan untuk C-organik menjadi sangat sesuai $\left(\mathrm{S}_{1}\right)$ dari kelas cukup sesuai $\left(\mathrm{S}_{2}\right)$.

Faktor pembatas N-total tanah dapat diperbaiki dengan tingkat pengelolaan sedang yaitu dengan pemupukan sesuai kebutuhan tanaman. Kebutuhan N-total tanaman padi sawah untuk kriteria sangat sesuai diperlukan $0,51 \%$ sedangkan ketersediaan $\mathrm{N}$ total yang terdapat pada tanah saat penelitian adalah $0,15 \%$ sehingga diperlukan penambahan $0,36 \%$ yang setara dengan $72 \mathrm{~kg} \mathrm{~N} / \mathrm{ha}$ atau $156,52 \mathrm{~kg}$ Urea/ha. Total pupuk yang dibutuhkan untuk padi sawah di daerah itu memerlukan tambahan rata-rata $25 \%$ sehingga perlu penambahan pupuk sebanyak $90 \mathrm{~kg} \mathrm{~N} / \mathrm{ha}$ atau 195,65 kg Urea/ha. Dengan begitu kesesuaian untuk N-total menjadi sangat sesuai $\left(\mathrm{S}_{1}\right)$ dari kelas cukup sesuai $\left(\mathrm{S}_{2}\right)$.

Hasil evaluasi kesesuaian lahan tingkat semi detil untuk tanaman padi sawah pada kesesuaian lahan aktual yaitu termasuk cukup sesuai dengan faktor pembatas $\mathrm{pH}, \mathrm{C}$-organik dan $\mathrm{N}$ total tanah (sub kelas $\mathrm{S}_{2}$ ). Kesesuaian lahan potensialnya termasuk kelas sangat sesuai $\left(\mathrm{S}_{1}\right)$. 
Tabel 4. Penilaian kesesuaian lahan tingkat semi detil untuk tanaman Padi sawah di Desa Hamparan Perak

\begin{tabular}{|c|c|c|c|c|c|c|}
\hline Karakteristik lahan & Nilai data & $\begin{array}{c}\text { Kesesuaian } \\
\text { lahan } \\
\text { aktual }\end{array}$ & $\begin{array}{c}\text { Faktor } \\
\text { pembatas } \\
\text { terberat }\end{array}$ & \multicolumn{2}{|c|}{$\begin{array}{c}\text { Usaha } \\
\text { perbaikan }\end{array}$} & $\begin{array}{c}\text { Kesesuaian } \\
\text { lahan } \\
\text { potensial }\end{array}$ \\
\hline Rejim suhu (t) & & & & & & \\
\hline Temperatur rata tahunan $\left({ }^{\circ} \mathrm{C}\right)$ & 27,01 & $\mathrm{~S}_{1}$ & & & & $\mathrm{~S}_{1}$ \\
\hline Ketersediaan air (w) & & & & & & \\
\hline Curah Hujan thn $(\mathrm{mm})$ & 2296 & $\mathrm{~S}_{1}$ & & & & $\mathrm{~S}_{1}$ \\
\hline Bulan Kering & $2-3$ & $\mathrm{~S}_{1}$ & & & & $\mathrm{~S}_{1}$ \\
\hline Kelembaban rata-rata $(\%)$ & 84,14 & $\mathrm{~S}_{1}$ & & & & $\mathrm{~S}_{1}$ \\
\hline Media perakaran (r) & & & & & & \\
\hline Drainase tanah & terhambat & $\mathrm{S}_{1}$ & & & & $\mathrm{~S}_{1}$ \\
\hline Tekstur tanah & berlempung & $\mathrm{S}_{1}$ & & & & $\mathrm{~S}_{1}$ \\
\hline Kedalaman efektif $(\mathrm{cm})$ & 76 & $\mathrm{~S}_{1}$ & & & & $\mathrm{~S}_{1}$ \\
\hline Retensi hara (f) & & & & & & \\
\hline $\mathrm{KTK}(\mathrm{me} / 100 \mathrm{~g})$ & $18,15(\mathrm{~S})$ & $\mathrm{S}_{1}$ & & & & $\mathrm{~S}_{1}$ \\
\hline Kejenuhan Basa (\%) & 106.01 (ST) & $\mathrm{S}_{1}$ & & & & $\mathrm{~S}_{1}$ \\
\hline $\mathrm{pH}$ tanah & 5,5 & $\mathrm{~S}_{2}$ & $\mathrm{f}$ & $\mathrm{G}$ & $\mathrm{S}$ & $\mathrm{S}_{1}$ \\
\hline C-organik (\%) & $0,87(\mathrm{SR})$ & $\mathrm{S}_{2}$ & $\mathrm{f}$ & $\mathrm{O}$ & $\mathrm{S}, \mathrm{T}$ & $\mathrm{S}_{1}$ \\
\hline Salinitas $(\mathrm{mmhos} / \mathrm{cm})(\mathrm{x})$ & 0,052 & $\mathrm{~S}_{1}$ & & & & $\mathrm{~S}_{1}$ \\
\hline Ketersediaan Hara (n) & & & & & & \\
\hline N-total $(\%)$ & $0,15(\mathrm{R})$ & $\mathrm{S}_{2}$ & $\mathrm{n}$ & $\mathrm{P}$ & $\mathrm{S}, \mathrm{T}$ & $\mathrm{S}_{1}$ \\
\hline $\mathrm{P}_{2} \mathrm{O}_{5}(\mathrm{ppm})$ & 27,28 (ST) & $\mathrm{S}_{1}$ & & & & $\mathrm{~S}_{1}$ \\
\hline $\mathrm{K}_{2} \mathrm{O}(\mathrm{mg} / 100 \mathrm{~g})$ & $0,61(\mathrm{~T})$ & $\mathrm{S}_{1}$ & & & & $\mathrm{~S}_{1}$ \\
\hline Penyiapan lahan (p) & & & & & & \\
\hline Batuan dipermukaan (\%) & $0-2$ & $\mathrm{~S}_{1}$ & & & & $\mathrm{~S}_{1}$ \\
\hline Singkapan batuan & 0 & $\mathrm{~S}_{1}$ & & & & $\mathrm{~S}_{1}$ \\
\hline Tingkat bahaya erosi (e) & & & & & & \\
\hline Bahaya erosi & SR & $\mathrm{S}_{1}$ & & & & $\mathrm{~S}_{1}$ \\
\hline Lereng $(\%)$ & 0 & $\mathrm{~S}_{1}$ & & & & $\mathrm{~S}_{1}$ \\
\hline Bahaya banjir (b) & & & & & & \\
\hline Periode banjir & F1 & $S_{1}$ & & & & $\mathrm{~S}_{1}$ \\
\hline Hasil kesesuaian lahar & & $\mathbf{S}_{2}(\mathbf{f n})$ & & & & $S_{1}$ \\
\hline $\begin{array}{l}\text { S1 }=\text { Sangat sesuai } \\
\text { S2 }=\text { Cukup sesuai } \\
\text { S3 }=\text { Sesuai Marginal }\end{array}$ & $\begin{array}{l}\mathrm{O}=\mathrm{H} \\
\mathrm{P}=\mathrm{I} \\
\mathrm{G}=\mathrm{C}\end{array}$ & $\begin{array}{l}\text { hn organik } \\
\text { emupukan } \\
\text { enangan }\end{array}$ & & & & \\
\hline
\end{tabular}

Menurut Abdurrahman (2002), tanaman padi yang menghasilkan 6 t/ha menyerap hara N, P dan K masing-masing sebesar $90 \mathrm{~kg} \mathrm{~N} / \mathrm{ha}, 16 \mathrm{Kg} \mathrm{P} / \mathrm{ha}$ dan $90 \mathrm{~kg} \mathrm{~K} / \mathrm{ha}$, padahal kemampuan tanah sawah menyediakan hara $\mathrm{N}, \mathrm{P}$ dan $\mathrm{K}$ masingmasing hanya $40-45 \mathrm{~kg} \mathrm{~N} / \mathrm{ha}, 12-19 \mathrm{~kg}$ $\mathrm{P} / \mathrm{ha}$ dan 60-100 $\mathrm{K} \mathrm{kg} / \mathrm{ha}$, sehingga terjadi kekurangan $50-55 \mathrm{~kg}$ N/ha, 0-4 kg P/ha dan 0-30 kg K/ha.

Penambahan pupuk organik dari kompos jerami padi sebanyak 2 ton/ha/musim tanam dapat menyumbang hara $\mathrm{K}$ setara $50 \mathrm{~kg} \mathrm{KCl} / \mathrm{ha} /$ musim (Dobbermann and Fairhurst, 2000 cit Zaini, 2012). Selain itu pengembalian jerami padi paling baik menurunkan kehilangan fosfat

Tanah dengan drainase agak terhambat sangat sesuai untuk tanaman lahan sawah. Pentingnya drainase pada lahan sawah berhubungan dengan supply oksigen (aerasi). Air permukaan yang mengandung banyak oksigen dapat masuk ke dalam tanah melalui perkolasi secara vertikal. Adanya supply oksigen dapat mencegah terjadinya potensial reduksi yang terlalu rendah, yang dapat menyebabkan tanaman keracunan besi dan mangan, asam organik tertentu atau kadang-kadang sulfida. Greenland (1985) mengemukakan, tanah yang 
mempunyai kelas drainase sangat terhambat juga tidak sesuai untuk dijadikan lahan sawah karena meskipun padi sawah tumbuh baik dalam keadaan tergenang, drainase pada tingkat tertentu masih sangat diperlukan.

PH tanah yang rendah dapat diatasi dengan penggenangan. Proses penggenangan dapat menaikkan $\mathrm{pH}$ mendekati netral atau bahkan netral (nilai 7) sehingga untuk pertumbuhan tanaman padi memungkinkan hasil panen signifikan.

Dari hasil analisis GIS diperoleh luas kesesuaian lahan aktual dan potensial Kecamatan Hamparan Perak Kabupaten Deli Serdang untuk tanaman padi sawah (Tabel 6) dan peta kesesuaian lahannya disajikan pada Gambar 4.
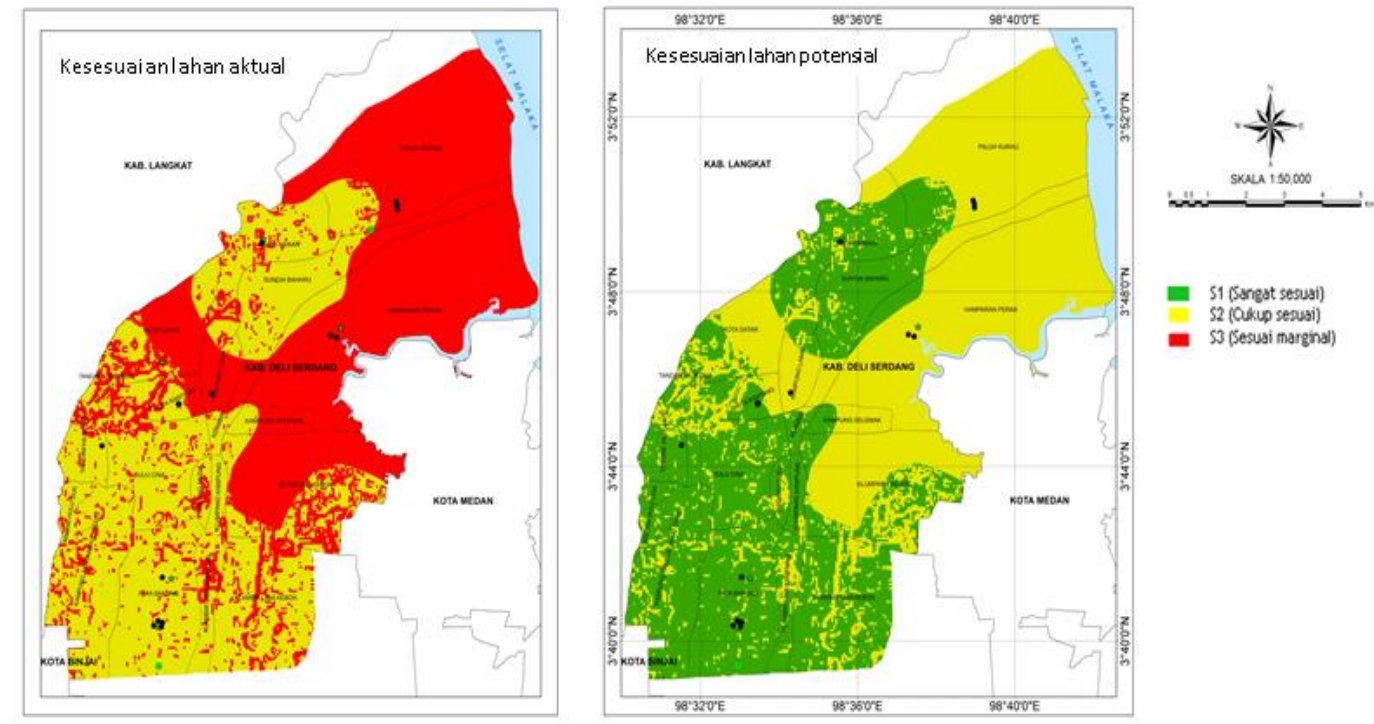

S1 (sangat sesual)

S2 (Oukno sesuar)

Gambar 3. Peta Kesesuaian lahan tanaman Padi sawah di Kecamatan Hamparan Perak Kabupaten Deli Serdang

Tabel 5. Luas kesesuaian lahan untuk tanaman padi sawah

\begin{tabular}{|c|c|c|c|}
\hline $\begin{array}{c}\text { Kesesuaian lahan } \\
\text { aktual }\end{array}$ & $\begin{array}{c}\text { Kesesuaian lahan } \\
\text { potensial }\end{array}$ & Luas (Ha) & Persenatse $(\%)$ \\
\hline $\mathrm{S}_{2}$ & $\mathrm{~S}_{1}$ & $14.093,883$ & 44,83 \\
\hline $\mathrm{S}_{3}$ & $\mathrm{~S}_{2}$ & $17.347,141$ & 55,17 \\
\hline \multicolumn{2}{|c|}{ Total } & $31.441,020$ & 100,00 \\
\hline
\end{tabular}

Sumber : Hasil analisis GIS

Karakteristik kedalaman efektif tanah di Kecamatan Hamparan Perak termasuk kategori dangkal sampai dalam. Ini bukan faktor penghambat untuk budidaya tanaman padi sawah. Pengolahan tanah dapat dilakukan jika lapisan padasnya tidak terlalu keras. Menurut Mu'minah (2009), Pengolahan 
tanah dapat menciptakan kondisi tanah yang baik bagi perkembangan akar, sehingga akar dapar menyerap unsur hara yang tersedia sehingga produksinya pada tanah yang di olah lebih tinggi dari pada tanah yang tidak di olah. mengemukakan bahwa pengolahan tanah minimum dapat meningkatkan produksi biomassa tanaman polongan, tongkol jagung dan jagung pipilan menjadi 130 sampai $165 \%$

\section{SIMPULAN}

Kelas kesesuaian lahan Kecamatan Hamparan Perak Kabupaten Deli Serdang adalah : (1) Untuk tanaman padi sawah termasuk kelas cukup sesuai $\left(\mathrm{S}_{2}\right)$ seluas 14.093, 883 ha dan kelas sesuai marginal $\left(\mathrm{S}_{3}\right)$ seluas $17.347,141$ ha dengan faktor pembatas retensi hara dan ketersediaan hara. (2) Untuk tanaman jagung termasuk kelas cukup sesuai $\left(\mathrm{S}_{2}\right)$ seluas 19.391, 019 ha dan kelas sesuai marginal $\left(\mathrm{S}_{3}\right)$ seluas $12.050,005$ ha dengan faktor pembatas retensi hara dan ketersediaan hara. (3) Untuk tanaman kedelai termasuk kelas sesuai marginal $\left(\mathrm{S}_{3}\right)$ seluas $31.441,024$ ha dengan faktor pembatas temperatur, curah hujan, drainase, retensi hara dan ketersediaan hara. (4) Untuk tanaman ubi kayu termasuk kelas sesuai marginal $\left(\mathrm{S}_{3}\right)$ seluas 31.441,024 ha dengan faktor pembatas curah hujan, drainase, retensi hara dan ketersediaan hara. (5) Untuk tanaman ubi jalar termasuk kelas sesuai marginal $\left(\mathrm{S}_{3}\right)$ seluas 31.441,024 ha dengan faktor pembatas temperatur, curah hujan, drainase, retensi hara dan ketersediaan hara. (6) Untuk tanaman sawo termasuk kelas cukup sesuai $\left(\mathrm{S}_{2}\right)$ seluas 17.660,583 ha dan kelas sesuai marginal $\left(\mathrm{S}_{3}\right)$ seluas 13.780,441 ha dengan faktor pembatas retensi hara dan ketersediaan hara. (7) Untuk tanaman mangga termasuk kelas sesuai marginal $\left(\mathrm{S}_{3}\right)$ seluas 31.441,024 ha dengan faktor pembatas curah hujan, drainase, retensi hara dan ketersediaan hara. (8) Untuk tanaman sukun termasuk kelas cukup sesuai $\left(\mathrm{S}_{2}\right)$ seluas 17.660,58 ha dan kelas sesuai marginal $\left(\mathrm{S}_{3}\right)$ seluas $13.780,44$ ha dengan faktor pembatas retensi hara dan ketersediaan hara

\section{UCAPAN TERIMAKASIH}

Selama melakukan penelitian dan penulisan tesis ini, Penulis banyak memperoleh bantuan moril dan materil dari berbagai pihak. Oleh karena itu, pada kesempatan ini penulis menyampaikan ucapan terima kasih kepada: (1) Bapak Prof. Dr. Ir. Abdul Rauf, MP., selaku Ketua Program Studi Magister Agroekoteknologi Fakultas Pertanian Universitas Sumatera Utara dan Ketua Komisi Pembimbing, (2) Ibu Dr. Deni Elfiati, SP, MP., selaku Anggota Komisi Pembimbing yang telah membimbing dan mengarahkan penulis dalam penulisan tesis ini. (3) Bapak Dr.Ir. Erwin Nyak Akoeb MS, Ibu Rahmawaty, S.Hut, MSi, Phd dan Bapak Dr. Ir. Mukhlis, MP selaku Komisi Pembanding/Penguji atas saran dan kritik yang diberikan (4) BPPSDM Kementerian Pertanian Republik Indonesia yang telah memberikan bantuan beasiswa tugas belajar (5) Stasiun BMKG (Badan Metereologi, Klimatologi dan Geofisika) Sampali Medan yang telah membantu memberikan data - data iklim di daerah penelitian

\section{DAFTAR PUSTAKA}

Abdurrachman, S. 2002. Pengelolaan hara spesifik Lokasi pada padi sawah. Makalah pada lokakarya Nasional Diversifikasi Tanaman. Penelitian dan pengembangan Sistem usaha Tani. Puslitbangtanak. Bogor 
Badan Penelitian dan Pengembangan Pertanian Kementerian Pertanian. 2012. Petunjuk Teknis Analisis Kimia Tanah, Tanaman, Air dan Pupuk. Edisi 2. Bogor. 204 hal

BPS. 2015. Berita Resmi Statistik Provinsi Sumatera Utara No. 22/03/12/Thn. XVIII, 2 Maret 2015. Tanaman pangan. www. Bps.go.id. Diakses tanggal 13 Mei 2015.

----- 2015. Luas wilayah Kabupaten Deli serdang. www.deliserdangkab.bps.go.i d. tanggal 29 Juni 2015

Dobermann, A and T. Fairhurs. 2000. Rice: nutrient disorders \& nutrient management. International Rice Research Institute and Potash \& Phosphate Institute/Potash \& Phosphate Institute of canada.

FAO. 1976. Framework for land Evaluation. FAO Soil Bulletin No. 32, Rome

Greenland, D.J. 1985. Phisical aspects of soil Management from soil taxonomy. P. 17-30 dalam Dariah, A dan F. Agus. 2015. Pengelolaan sifat Fisik Tanah Sawah Bukaan baru. http://balittanah.litbang.perta nian.go.id/. Di akses tanggal 30 Juni 2015.

Hardjowigeno, S dan Widiamaka. 2007.

Evaluasi Kesesuaian Lahan dan Perencanaan Tataguna Lahan. Universitas Gadjah Mada Press. Yogyakarta. 352 hal.

Howeler, R.H. 2002. Casava mineral nutrition and fertilization. In R.J.Hillock, J.M.Thresh and A.C Belloti (ed) Cassava Biologi. Production and
Utilization. Pp:115-147. CABI Publishing, CAB International Wallingford. Oxon

Indranada, H. K. 1986. Pengelolaan Kesuburan Tanah. Jakarta: PT Bina Aksara

Mu'minah. 2009. Pengaruh Pengolhan tanah dan Pemberian Mulsa Jerami terhadap Produksi Tanaman Jagung, Kacang Tanah dan Erosi Tanah. Jurnal Agrisistem. Vol.5 No 1 ; 40-46

Ritung, S, K. Nugroho, A. Mulyani dan E. Suryani. 2011. Petunjuk Teknis Evaluasi Lahan Untuk Komoditas Pertanian (edisi revisi). Balai Besar Penelitian dan Pengembangan Sumberdaya Lahan Pertanian, Badan Penelitian dan Pengembangan Pertanian. Bogor. 168 hal.

Suhedy, T. 2014. Programa Balai Penyuluhan Pertanian (BPP) Kecamatan Hamparan Perak. Dinas Pertanian Kabupaten Deli Serdang. 30 hal

Tisdale, S.L., W.L. Nelson, and J.D Beaton. 1985. Soil fertility and fertilizer, four Edition Mac Millan Publ. Co. Inc. New.

Woolfe, J.A. 1989. Nutritional aspects of sweetpopato roots and leaves. Improvement of sweetpotato (Ipomoea batatas) in Asia. CIP. Lima, Peru. P. 167-182.

Zaini, Z. 2012. Pupuk Majemuk dan Pemupukan Hara Spesifik Lokasi pada Padi Sawah. Buletin Iptek Tanaman Pangan Vol 7 No $1: 1-7$ 